\title{
Studies on Microbiological Quality of Ice-Creams Sold in and Around Greater Hyderabad Municipal Cooperation
}

\author{
P. P. Sirisha*, P. Sravani and N. Krishnaiah \\ Department of Veterinary Public Health and Epidemiology, \\ College of Veterinary Science, Rajendranagar, Hyderabad, India \\ *Corresponding author
}

\section{A B S T R A C T}

\section{Keywords}

Ice-cream, microbiological quality, pathogens, public health

\section{Article Info}

Accepted:

12 February 2020

Available Online:

10 March 2020
The microbiological quality of ice-cream samples collected from co-operative, branded private and non-branded sectors sold in and around Greater Hyderabad Municipal Co-operation, Telangana state was studied. The standard plate count, coliform count, faecal coliform count and yeast and mould counts were $2.51 \times 10^{5}$ $\mathrm{CFU} / \mathrm{gm}, \quad 8.05 \times 10^{2} \mathrm{CFU} / \mathrm{gm}, 2.57 \times 10^{2} \mathrm{CFU} / \mathrm{gm}$, and $2.66 \times 10^{2} \mathrm{CFU} / \mathrm{gm}$ from cooperative sector, $3.08 \times 10^{5} \mathrm{CFU} / \mathrm{gm}, 2.2 \times 10^{3} \mathrm{CFU} / \mathrm{gm}, 9.57 \times 10^{2} \mathrm{CFU} / \mathrm{gm}$ and $3.87 \times 10^{3} \mathrm{CFU} / \mathrm{gm}$ from branded private sector, $4.99 \times 10^{7} \mathrm{CFU} / \mathrm{gm}, 9.68 \times 10^{5}$ CFU/gm, $4.32 \times 10^{4} \mathrm{CFU} / \mathrm{gm}$ and $4.28 \times 10^{4} \mathrm{CFU} / \mathrm{gm}$ from non-branded sector respectively. The incidence of Staphylococcus spp. was $60 \%$ from co-operative sector, 53\% from branded private sector and $100 \%$ from non-branded sector. The incidence of Salmonella spp. was 40\%, 73\%, 90\% from co-operative, branded private, and non-branded sectors respectively. The incidences of Escherichia coli, Listeria spp., and Bacillus spp. was 63\%, 53\%, 43\% from co-operative sector, $86 \%, 73 \%, 80 \%$ from branded private sector and $100 \%, 76 \%$, and $93 \%$ from nonbranded sector respectively. The microbiological quality of ice-creams was good from cooperative sector followed by branded sector and fair from non-branded sector.

\section{Introduction}

Ice cream is a delicious frozen western product containing milk, sweetening and stabilising agents together with flavouring and colouring matter (Graff-Johnson, 1974). It is consumed by large segments of population and more popular among children and inevitable during feasts. The production and consumption of ice creams and other frozen dairy products is increasing day by day all over the world.

The microbiological quality of ice cream sold in retail shops mainly depends on contamination during product handling as well as efficiency and sanitary conditions during frozen storage. The high content of 
nutrients like lactose and proteins and its neutral $\mathrm{pH}$ make it an excellent growth medium for microbes, some of which may cause serious disease outbreaks (Ahmed et al., 2009). Problems in maintaining cold chain during marketing and inadequate pasteurisation are the main sources of contamination in India, apart from contaminated raw materials, improper handling and storage (Verma et al., 1992). Microbiological quality of ice cream is determined by TVC, coliform count, faecal coliform count, yeast and mould count and certain pathogen like Staphylococcus spp., Salmonella spp., Escherichia coli, Listeria, Bacillus spp. etc.

During last few decades, it has been observed that consumption of contaminated ice creams was responsible for disease outbreaks in many countries (Djuretic et al., 1997). Since the consumption of ice cream was higher among children of vulnerable age groups, there is need to maintain high microbial safety standards (Champagne et al., 1994). Presently, majority of ice creams sold in and around GHMC especially brand less was not up to mark with reference to microbial quality. So an attempt was made to study the microbial quality and presence of certain pathogens in the ice creams from different sources in and around GHMC.

\section{Materials and Methods}

\section{Sample Collection}

For study purpose, the samples were divided into three categories: co-operative, branded and non-branded sources. Samples were collected from the sales centres, packed in thermocol box with ice, transported and stored at $-20^{\circ} \mathrm{C}$ in the department of Veterinary Public Health and Epidemiology, College of veterinary science, Rajendranagar, Hyderabad till further testing.

\section{Preparation of dilutions}

For serial dilutions preparation, $10 \mathrm{gm}$ of ice cream was aseptically transferred into $90 \mathrm{ml}$ of sterile distilled water and homogenised by vertex. Subsequent serial dilutions were prepared up to $10^{6}$.

\section{Media preparation}

Various media like nutrient agar for Total viable counts, Mc Conkey agar for coliform and faecal coliforms and potato dextrose agar for yeast and mould count were used as per the methods described in IS:2802 (1964). For studying the incidence and counts of pathogenic organism Mannitol salt agar for Staphylococcus spp., Selenite F broth for Listeria spp., XLD for Salmonella spp., Eosin methylene blue for Escherichia coli, Mannitol yeast extract polymixin agar for Bacillus spp., were used. One $\mathrm{ml}$ of dilutions serially from $10^{5}$ and $10^{6}$ for total viable count, $10^{1}$ to $10^{4}$ for coliforms and specified dilutions for different microorganisms are transferred to petri dishes and respective liquid media was added and allowed to set. Petridishes for total viable count, coliforms and other pathogens were incubated at $35^{\circ} \mathrm{C}$ for 24 to 48 hours, whereas for faecal coliforms incubated at $44.5^{\circ} \mathrm{C}$ for 24 to 48 hours and counts were taken with the help of colony counter. The incubation period for yeast and moulds was 3 to 5 days. The pathogenic microorganisms were confirmed with various specified biochemical tests.

\section{Results and Discussion}

The total viable count, coliform counts, faecal coliform counts, yeast and mould counts of ice cream samples collected from different sources were presented in table 1 . The total viable cell count in the ice cream for cooperative sector were least $\left(2.51 \times 10^{5}\right.$ CFU/gm) which was within the limits 
specified under BIS (2.5 lakhs /gm), almost similar to the findings of Nelapati et al., (2009) who reported counts of $2.62 \times 10^{5}$ in the sample from co-operative sector. The total viable cell Count in the samples from unbranded sources was very high $\left(4.99 \times 10^{7}\right.$ CFU/gm).

Counts of $4.5 \times 10^{5} \mathrm{CFU} / \mathrm{gm}, \quad 3.07 \times 10^{5}$ $\mathrm{CFU} / \mathrm{gm}$ and $1.2 \times 10^{3} \mathrm{CFU} / \mathrm{gm}$ reported by Warke et al., (2000), Nelapati et al., (2009) and Jadav and Raut (2014) respectively were less than the counts observed in the present study $\left(3.08 \times 10^{6} \mathrm{CFU} / \mathrm{gm}\right)$ for the samples collected from branded private sector. The SPC count in the samples from unbranded source was $4.99 \times 10^{7} \mathrm{CFU} / \mathrm{gm}$ in present study, was less than the counts $\left(0.1 \times 10^{9}\right.$ to $\left.1.02 \times 10^{9} \mathrm{CFU} / \mathrm{gm}\right)$ reported by Kumar et al., (2011) and higher than the counts $1.2 \times 10^{5}$ to $\left.7 \times 10^{5} \mathrm{CFU} / \mathrm{gm}\right)$ reported by Jadav and Raut (2014).

The coliform counts in the present study was $8.05 \times 10^{2} \mathrm{CFU} / \mathrm{gm}, 2.2 \times 10^{3} \mathrm{CFU} / \mathrm{gm}$ and $9.68 \times 10^{5} \mathrm{CFU} / \mathrm{gm}$ from co-operative, branded and non-branded respectively, which were higher than counts reported by Nelapati et al., (2009) from the three sources. Singh et al., (1976) reported coliform count similar to the counts from co-operative sector, where as Patel and Vyas (1971) reported counts similar to branded private sector samples in present study, Thattil et al., (1972) reported low count (442/gm). Warke et al., (2000) reported coliform count of $9.72 \times 10^{1}$ to $6 \times 10^{3}$ $\mathrm{CFU} / \mathrm{gm}$ in the samples from branded private sector, which was almost similar to counts $\left(2.2 \times 10^{3} \mathrm{CFU} / \mathrm{gm}\right)$ observed in the present study.

Coliform count of $9.68 \times 10^{5} \mathrm{CFU} / \mathrm{gm}$ was observed in present study from unbranded samples, which was almost similar to the count $\left(4.5 \times 10^{5} \mathrm{CFU} / \mathrm{gm}\right)$ reported by Harsh Kumar et al., (2011) and more than the counts of $2.3 \times 10^{3} \mathrm{CFU} / \mathrm{gm}$ and $2.48 \times 10^{4} \mathrm{CFU} / \mathrm{gm}$ reported by Warke et al., (2000) and Ambily and Bena (2012) respectively .

The yeast and mould counts in the sample from branded private sector was $3.87 \times 10^{3}$ $\mathrm{CFU} / \mathrm{gm}$ in the present study, was almost similar to counts of $4 \times 10^{3} \mathrm{CFU} / \mathrm{gm}$ and $3.87 \times 10^{3} \mathrm{CFU} / \mathrm{gm}$ reported by Ojokoh (2006) and Nelapati et al., (2009) respectively . A count of $4.28 \times 10^{4} \mathrm{CFU} / \mathrm{gm}$ in the sample from unbranded sources in the present study was more than the count of $1 \times 10^{3} \mathrm{CFU} / \mathrm{gm}$ observed by Yaman et al., (2006) and almost similar to the counts of $1.03 \times 10^{3} \mathrm{CFU} / \mathrm{gm}$ reported by Nelapati et al., (2009). The yeast and mould counts in the sample from cooperative sector was $2.66 \times 10^{2} \mathrm{CFU} / \mathrm{gm}$ in the present study,was less than the counts of $2.66 \times 10^{3} \mathrm{CFU} / \mathrm{gm}$ reported by Nelapati et al., (2009).

\section{Incidence of pathogenic microorganisms}

The incidence of Staphylococcus spp., Salmonella spp., Escherichia coli, Listeria spp. and Bacillus spp. in ice-cream samples from different sources was presented in table 2.

The incidence of Staphylococcus spp. in the present study was $100 \%$ from non-branded sector, which was similar to the findings of Ikenebometi and Ogaguria (1993) and higher than the incidence $(40 \%)$ reported by Jadav and Raut (2014). The incidence of Staphylococcus spp. In the ice-cream samples from branded private sector was 53\% in the present study, which was less than incidence $(100 \%)$ reported by Ojokoh (2006). The incidence of Staphylococcus spp. in cooperative sector samples in present study was $60 \%$. The incidence of Salmonella spp. in branded private ice-cream samples in the present study was found to be higher $(73 \%)$ than the incidence $(60 \%)$ observed by Ojokoh 
(2006). Salmonella spp. incidence in cooperative was $40 \%$ which was less than branded private sector where as, for nonbranded sector the incidence was $90 \%$, which was higher than other two sources.

The incidence of Escherichia coli in the icecream samples from non- branded category was $100 \%$ in the present study, which was very high compared to the incidence $(40 \%)$ reported byJadhav and Raut (2011). The incidence was $63 \%$ and $86 \%$ in co-operative and branded private ice cream samples respectively in the present study. The Escherichia coli incidence in co-operative and branded private samples was also high and alarming for public health.

Incidence of Listeria spp. in the present study was $53 \%$ in co-operative sector ice-cream samples. Warke et al., (2000) reported 53\% incidence of Listeria spp. in branded private sector ice-cream samples, which was less than the incidence of $73 \%$ observed in the samples from branded private sector, but similar to the incidence in co-operative sector samples observed in the present study. The incidence of Listeria spp. in the ice-cream samples from non- branded sector was $76 \%$, which was lower than the incidence $(100 \%)$, reported by Warke et al., (2000).

The incidence of Bacillus spp. in the samples from co-operative sector was less (43\%), which was less than the incidence in the samples from branded private and nonbranded sectors in the present study. Warke et al., (2000) reported 26.6\% incidence of Bacillus spp. in the ice-cream samples from branded private sector, which was very less than the incidence of $80 \%$ observed the present study. Yaman (2006) reported very less incidence (19\%) of Bacillus spp., in the ice-cream samples from non-branded sector compared to higher incidence $(93 \%)$ observed in the present study.

\section{Pathogenic microorganisms counts}

The pathogenic counts of Staphylococcus spp., Salmonella spp., Escherichia coli, Listeria spp. and Bacillus spp. in ice-cream samples from different sources was presented in table 3 .

The Escherichia coli counts in the ice-cream samples from non-branded sector was high $\left(9.6 \times 10^{4} \mathrm{CFU} / \mathrm{gm}\right)$, least in co-operative sector $\left(4.8 \times 10^{2} \mathrm{CFU} / \mathrm{gm}\right)$, and in between in branded private sector $\left(3.52 \times 10^{3} \mathrm{CFU} / \mathrm{gm}\right)$.

The counts of Staphylococcus spp. in the present study from co-operative sector ice cream samples was $1.2 \times 10^{3} \mathrm{CFU} / \mathrm{gm}$, which was higher than the counts of $1.07 \times 10^{2}$ CFU/gm reported by Ambily and Been (2012). The counts of Staphylococcus spp. in the samples from non-branded sector was $3.7 \times 10^{4} \mathrm{CFU} / \mathrm{gm}$, which was higher than the counts of $1 \times 10^{2} \mathrm{CFU} / \mathrm{gm}$, reported by Yaman et al., (2006). The counts in the samples from branded private sector was $5.82 \times 10^{3} \mathrm{CFU} / \mathrm{gm}$, which was in between the counts of cooperative and non-branded sector in the present study.

The counts for salmonella spp. was $5.8 \times 10^{1}$ $\mathrm{CFU} / \mathrm{gm}$ in branded private sector, which was higher than the counts of $1 \times 101 \mathrm{CFU} / \mathrm{gm}$ reported by Jadav and Raut (2014). The counts of $3.8 \times 10^{2} \mathrm{CFU} / \mathrm{gm}$ was observed in the samples from non-branded sector in the present study, was less than the counts of $8 \times 10^{1} \mathrm{CFU} / \mathrm{gm}$ reported by Jadav and Raut (2014).

The counts of salmonella spp. from cooperative sector was $1.8 \times 10^{1} \mathrm{CFU} / \mathrm{gm}$, was less compared to the counts from branded private and unbranded sectors in the present study. The Listeria spp. counts from nonbranded sector was high $\left(6.2 \times 10^{2} \mathrm{CFU} / \mathrm{gm}\right)$, intermediate in branded private sector 
$\left(8.5 \times 10^{1} \mathrm{CFU} / \mathrm{gm}\right)$ and least in co-operative sector $\left(2.5 \times 10^{1} \mathrm{CFU} / \mathrm{gm}\right)$ in the present study. The counts for Bacillus spp. in the present study from non-branded sector was $3.56 \times 10^{3}$ $\mathrm{CFU} / \mathrm{gm}$, which was less than the counts of $1 \times 10^{4} \mathrm{CFU} / \mathrm{gm}$ reported by Yaman et al.,
(2006). The counts from branded private sector $\left(5.2 \times 10^{1} \mathrm{CFU} / \mathrm{gm}\right)$, was intermediate and the counts from co-operative sector $\left(1.8 \times 10^{1} \mathrm{CFU} / \mathrm{gm}\right)$ and was least in the present study.

Table.1 Total viable counts, coliform count, faecal coliform count and yeast and mould counts in ice-cream samples from different sources (CFU/gm)

\begin{tabular}{|l|l|l|l|l|}
\hline \multicolumn{1}{|c|}{ Source } & \multicolumn{1}{|c|}{ SPC/ml } & \multicolumn{1}{|c|}{ Coliform/ml } & \multicolumn{1}{c|}{$\begin{array}{c}\text { Faecal } \\
\text { coliform }\end{array}$} & \multicolumn{1}{c|}{$\begin{array}{c}\text { Yeast and } \\
\text { moulds }\end{array}$} \\
\hline Co-operative & $2.51 \times 10^{5}$ & $8.05 \times 10^{2}$ & $2.57 \times 10^{2}$ & $2.66 \times 10^{2}$ \\
\hline Branded & $3.08 \times 10^{5}$ & $2.2 \times 10^{3}$ & $9.57 \times 10^{2}$ & $3.87 \times 10^{3}$ \\
\hline Non-Branded & $4.99 \times 10^{7}$ & $9.68 \times 10^{5}$ & $4.32 \times 10^{4}$ & $4.28 \times 10^{4}$ \\
\hline
\end{tabular}

Table.2 Incidence rates of microorganisms in the ice-cream samples from different samples

\begin{tabular}{|l|c|c|c|c|c|}
\hline \multicolumn{1}{|c|}{ Incidence } & $\begin{array}{c}\text { Staphylococcus } \\
\text { spp. }\end{array}$ & $\begin{array}{c}\text { Salmonella } \\
\text { spp. }\end{array}$ & $\begin{array}{c}\text { Escherichia } \\
\text { Coli }\end{array}$ & Listeria & Bacillus spp. \\
\hline Co-operative & $60 \%$ & $40 \%$ & $63 \%$ & $53 \%$ & $43 \%$ \\
\hline Branded & $53 \%$ & $73 \%$ & $86 \%$ & $73 \%$ & $80 \%$ \\
\hline Non-branded & $100 \%$ & $90 \%$ & $100 \%$ & $76 \%$ & $93 \%$ \\
\hline
\end{tabular}

Table.3 Pathogenic micro-organisms counts in ice-cream samples from different sources $(\mathrm{CFU} / \mathrm{gm})$

\begin{tabular}{|l|l|c|c|c|c|}
\hline \multicolumn{1}{|c|}{ Incidence } & $\begin{array}{c}\text { Staphylococcus } \\
\text { spp. }\end{array}$ & $\begin{array}{c}\text { Salmonella } \\
\text { spp. }\end{array}$ & $\begin{array}{c}\text { Escherichia } \\
\text { coli }\end{array}$ & $\begin{array}{c}\text { Listeria } \\
\text { spp. }\end{array}$ & $\begin{array}{c}\text { Bacillus } \\
\text { spp. }\end{array}$ \\
\hline $\begin{array}{l}\text { Co- } \\
\text { operative }\end{array}$ & $1.2 \times 10^{3}$ & $1.8 \times 10^{1}$ & $4.8 \times 10^{2}$ & $2.5 \times 10^{1}$ & $1.8 \times 10^{1}$ \\
\hline Branded & $5.82 \times 10^{3}$ & $5.8 \times 10^{1}$ & $3.52 \times 10^{3}$ & $8.5 \times 10^{1}$ & $5.2 \times 10^{1}$ \\
\hline $\begin{array}{l}\text { Non- } \\
\text { Branded }\end{array}$ & $3.7 \times 10^{4}$ & $3.8 \times 10^{2}$ & $9.6 \times 10^{4}$ & $6.2 \times 10^{2}$ & $3.56 \times 10^{3}$ \\
\hline
\end{tabular}

The general microbial quality, incidence and counts of certain pathogenic microorganisms like Staphylococcus spp., Salmonella spp., Escherichia coli., Listeria spp. and Bacillus spp. was very high in the samples from nonbranded sector, good from cooperative sector and optimum from branded private sector.
Infants and children, the lovers of ice-cream may consume more amount of ice-cream mostly from non-branded sector due to cheaper price, so, care should be taken while consuming ice-creams from brand less or road side sellers. 


\section{Acknowledgement}

We are grateful to the Department of Veterinary Public Health and epidemiology, College of Veterinary Science, P. V. Narsimha Rao Telangana Veterinary University, for providing the necessary facilities in carrying out this work.

\section{References}

Ambily, R. and Beena, A.K. 2012. Bacteriological quality of ice cream marketed in Thrissur town, Kerala, India. Vet. World, Vol 5 (12): 738-741.

Bhushan Reddy., B.B., Ranganadham, M., Padmanabha Reddy, V., Shivekumar and Kotilinga Reddy, Y. 1994. Studies on the quality of ice cream sold in Tirupathi town. Indian J. Dairy Sci., 47:215-218.

Guha, A.K., Das, H.N., Roy, R. and Dewan, M.L. 1979. Microorganisms in ice creams and their public health significance. J. Food Sci. Tech., 16 : 161-164.

IS:2802. 1964. Indian Standard specification for ice cream. Bureau of Indian Standards, Manak Bhawan, New Delhi.
Jadhav, A.S. and Raut, P.D. 2014. Evaluation of microbiological quality of ice creams marketed in Kolhapur City, Maharashtra, India. Int Journal of Current Microbiol and Applied Sci, 2 (9) 78-84.

Nelapati, S., Krishnaiah, N., and Kiranmayi, B. 2009. Studies of Physio-Chemical and Microbiological Quality of Ice creams Sold in and around Greater Municipal Corporation, J. Vet. Pub. Hlth., 7(2) : 121-124.

Rahul Warke, Anu Kamat, Madhusudan Kamat and Paul Thomas. 2000. Incidence of pathogenic psychrotrophs in ice creams sold in some retail outlets in Mumbai, India. Elsevier, Food Control., 11 (77-83).

Rao, L.V., Ali, M.P., Krishnaiah, N., Reddy, C.R. and Ram Rao, M. 1988. Soft serve frozen dessert made with sweetened milk and plain ice cream mix. Indian J. Dairy. Sci. 41 : 513-515.

Yaman, H., Elmali, M., Ulukanli, Z., Tuzcu, M., and Genctav, K. 2006. Microbial quality of ice cream sold openly by retail outlets in Turkey. Revue Med. Vet., 157, 10, 457-462.

\section{How to cite this article:}

Sirisha. P .P., P. Sravani and N. Krishnaiah. 2020. Studies on Microbiological Quality of IceCreams Sold in and Around Greater Hyderabad Municipal Cooperation. Int.J.Curr.Microbiol.App.Sci. 9(03): 1814-1819. doi: https://doi.org/10.20546/ijcmas.2020.903.210 